\title{
Performance Management of Transmission Line Tower Foundations against Corrosion by Non Destructive Testing
}

\author{
R.Krishnasamy, G.Shyamala, S.Christian Johnson, K.Sabarinathan, S.M.Sakthivel, K.Rajesh \\ Kumar
}

\begin{abstract}
In this paper, corrosion in overhead line foundations in different field environmental conditions (plain, agricultural and coastal/industrial region) have been detected by non-destructive test methods such as Half-cell potential test, Ultrasonic pulse velocity test, Rebound hammer test, chemical analysis of soil and Transmission Line Tower (TLT) footing concrete samples and scanning electron microscope (SEM) analysis of deteriorated tower footing concrete. The collected soil samples have been analyzed for chemicals and the TLT coping concrete samples have been tested using scanning electron microscope. The correlation between the test values, mineralogical composition of soil and concrete samples at tower footing level is presented.
\end{abstract}

Keywords : Corrosion, Non Destructive Testing, SEM, TLT

\section{INTRODUCTION}

A ll over the world, the transmission towers have to be erected in open lands or dense forests where an extreme climatic condition exists. Transmission towers existing in coastal areas are affected by chloride environments. The Overhead lines erected in industrial areas are very much affected by industrial wastes and other chemical pollutants where sulphate/sulphide attacks are predominant. Overhead lines running through agricultural fields are affected by fertilizers like ammonia and other manures. Such environments cause adverse effect on durability of TLT foundations leading to deterioration of chimney concrete, and corrosion of stubs. More and more investigative studies are

Revised Manuscript Received on February 05, 2020.

* Correspondence Author

R.Krishnasamy*, Civil Department, Erode Sengunthar Engineering College, Erode, India. Email: krishnaceans@gmail.com

G.Shyamala, Professor, Civil Engineering Department, S R Engineering College, Warangal, India, E-mail: shyamala@srecwarangal.ac.in

S.Christian Johnson, Civil Department, Erode Sengunthar Engineering College, Erode, India. Email: cjnlef@gmail.com

K.Sabarinathan, Civil Department, Excel Engineering College, Namakkal, India. Email: civilsaba@gmail.com India. Email: sakthicvl24@gmail.com

K.Rajesh Kumar, Associate Professor, Civil Engineering Department, S $\mathrm{R}$ Engineering College, Warangal, India, E-mail: dr,rajeshkumar@srecwarangal.ac.in

(C) The Authors. Published by Blue Eyes Intelligence Engineering and Sciences Publication (BEIESP). This is an open access article under the CC BY-NC-ND license (http://creativecommons.org/licenses/by-nc-nd/4.0/)
S.M.Sakthivel Civil Department, Excel Engineering College, Namakkal,

going on around the world to detect, prevent and to repair the corrosion defects in TLT foundations.

\section{LITERATURE REVIEW}

Physical, Chemical and electro chemical parameters, studied on transmission line tower stubs excavated from inland and coastal areas have been presented. A methodology for rehabilitation of transmission tower stubs has been discussed by S.Christian Johnson and Dr. G.Thirugnanam [1]. Certain guidelines for the design and maintenance of a cathodic protection system for Transmission and distribution structures have been presented by Peyman Taheri [2]. A Novel technique of retrofitting of corrosion damaged RCC foundations of transmission towers exposed to marine environment using wrapping of fiber reinforced plastic (FRP) composite have been investigated by Mangesh V. Joshi [3]. It is experienced that FRP composite in addition to strengthening a concrete member, provides a barrier to protect the concrete from an aggressive environment. Investigations on application of protective coatings upon the reinforcements and addition of admixtures in the concrete have been carried out Protective methods like O-ring provision in the stub angle concrete interface, various levels of protective methods including nano penetrant coatings to combat the crevice corrosion, has been suggested for field applications in marine environment. Several non destructive techniques like half cell potential test, rebound hammer test, carbonation test including experimental investigation in the laboratory have been elaborately carried out by S.Christian Johnson and Dr. G.Thirugnanam [4]. Matthew Bruce Barragan [5] has been followed best practices for corrosion assessment, prevention and remediation for WS transmission line poles are discussed, and case-specific recommendations are made for WS poles located in operating environments that feature a representative range of atmospheric corrosivity characteristics.

\section{EXPERIMENTAL WORK}

As India has a large coastal line and a number of cities and metropolis located in the vicinity of coastal belt including vast agricultural, industrial and hilly areas TLT foundations in these areas are witnessing continuous deterioration. However publications on investigative studies involving ultrasonic pulse velocity test, scanning electron microscope images for better performance management of Transmission and distribution utilities are scarce. 
Hence there is a need to conduct the following investigative studies which will help better performance management of such vital installations.
A. Condition assessment of tower footing concrete using Non destructive testing (NDT) techniques.
B. Chemical analysis of soil samples
C. Chemical analysis of tower footing concrete samples
D. SEM analysis of tower footing concrete samples

\section{A. Condition assessment of tower footing concrete using} Non destructive testing (NDT) techniques.

Conduction of existing transmission line tower foundation in plain, agricultural and coastal/industrial region have been proposed in this work and the details of TLT location, TLT Voltage, Number of TLT considered for conducting NDT's are furnished in Table I. It is confirmed from the officials of state power transmission utilise in Tamil Nadu, India that these location have encountered incidences of corrosion defects at the TLT footing level now and then.

Table- I: Details of TLT locations, voltage and numbers

\begin{tabular}{|c|c|c|c|}
\hline Parameter & Plain (mild) & $\begin{array}{c}\text { Agricultural } \\
\text { (moderate) }\end{array}$ & $\begin{array}{c}\text { Coastal/Industri } \\
\text { al (extreme) }\end{array}$ \\
\hline TLT location & $\begin{array}{c}\text { Komarapalayam } \\
\text { (KPM), } \\
\text { Nammakkal } \\
\text { District }\end{array}$ & $\begin{array}{c}\text { Mettur } \\
\text { (MTPS), } \\
\text { Salem District }\end{array}$ & $\begin{array}{c}\text { Atthipet (NCTPS), } \\
\text { Thiruvallur } \\
\text { District, Chennai }\end{array}$ \\
\hline TLT Voltage & $110 \mathrm{kV}$ & $230 \mathrm{kV}$ & $230 \mathrm{kV}$ \\
\hline $\begin{array}{c}\text { Number of } \\
\text { TLT }\end{array}$ & 10 & 10 & 10 \\
\hline
\end{tabular}

In order to manage the performance of such TLT, it has been proposed to conduct the following NDT's as per ASTM/IS standards. Half cell potential test (HCP), Ultrasonic pulse velocity test (UPV) and rebound hammer tests $(\mathrm{RH})$ have been conducted upon the coping part of each above towers as per the ASTM and IS Standards mentioned in the Table 2.

\section{Table- II: NDTs standards}

\begin{tabular}{|c|c|c|}
\hline $\begin{array}{c}\text { S.N } \\
\mathbf{0}\end{array}$ & $\begin{array}{c}\text { NDT } \\
\text { methods }\end{array}$ & ASTM/IS standards \\
\hline 1 & HCP test & ASTM 876 c-90 \\
\hline 2 & UPV test & IS 13311 (P 1):1992 \\
\hline 3 & RH test & IS 13311 (P 2):1992 \\
\hline
\end{tabular}

Six readings in each tower footings have been taken and average value has been recorded. The non destructive test values have been compared with the norms stipulated in the ASTM/IS Standards and the quality status of coping concrete is recorded in the Table VI. Fig. 1 depicts the conduction of NDT's in plain, agricultural and coastal/industrial regions.

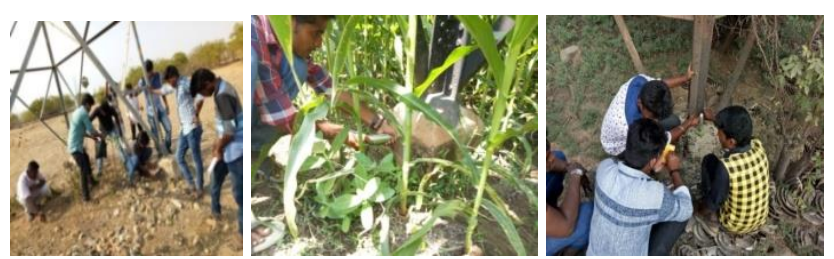

Fig. 1. NDT test in Plain, Agricultural and Coastal/Industrial Region
The standards of quality of concrete using Half cell potential, Ultrasonic pulse velocity test and Rebound hammer are furnished in the Table III to V.

Table- III: Probability of reinforcement corrosion

\begin{tabular}{|c|c|c|}
\hline \multicolumn{2}{|c|}{ Half cell potential (HCP) values } & \multirow{2}{*}{ Corrosion condition } \\
\cline { 1 - 2 } ( mV vs. SCE) & ( mV vs. CSE) & \\
\hline$<-426$ & $<-500$ & Severe corrosion \\
\hline$<-276$ & $<-350$ & High ( $<90 \%$ of corrosion) \\
\hline-126 to -275 & -350 to -200 & Intermediate corrosion risk \\
\hline$>-125$ & $>-200$ & Low (10\% risk of corrosion) \\
\hline
\end{tabular}

Table- IV: Longitudinal pulse velocity vs. Quality of concrete

\begin{tabular}{|c|c|c|}
\hline $\begin{array}{c}\text { Longitudinal } \\
\text { pulse velocity } \\
\text { (km/s) }\end{array}$ & $\begin{array}{c}\text { Approximate } \\
\text { compressive } \\
\text { strength } \\
\text { (N/mm } \mathbf{2})\end{array}$ & $\begin{array}{c}\text { Quality of } \\
\text { concrete }\end{array}$ \\
\hline Below 2.0 & --- & Very poor \\
\hline 2.0 to 3.0 & 4.0 & Poor \\
\hline 3.0 to 3.5 & Upto 10 & Fairly good \\
\hline 3.5 to 4.0 & Upto 25 & Good \\
\hline 4.0 to 4.5 & Upto 40 & Very good \\
\hline Above 4.5 & Upto 40 & Excellent \\
\hline
\end{tabular}

Table- V: Quality of concrete according to rebound number

\begin{tabular}{|c|c|}
\hline $\begin{array}{c}\text { Average } \\
\text { rebound } \\
\text { number }\end{array}$ & Quality of concrete \\
\hline$>40$ & Very good hard layer \\
\hline $30-40$ & Good layer \\
\hline $20-30$ & Fair \\
\hline$<20$ & Poor \\
\hline 0 & Delaminated \\
\hline
\end{tabular}

\section{B. Chemical analysis of soil samples}

In order to understand the influence of chemicals present in the soil around the TLT stub, soil samples have been collected from the locations considered and they were tested in a reputed research lab. The soil samples collected around the tower in different region shown in Fig. 2.
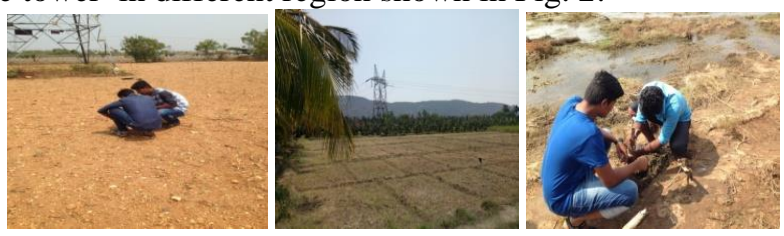

Fig. 2 Collection of Soil Samples in different region

\section{Chemical analysis of tower footing concrete samples}

Besides testing the soil around the stub, some of the loosened concrete from the TLT coping in the selected locations also analyzed for chemicals from the same reputed/certified testing lab. The mineralogical composition of such concrete samples is furnished in Fig. 7.

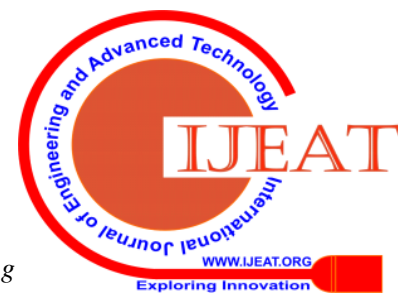




\section{SEM Analysis of tower footing concrete samples}

In addition to investigate the tower coping concrete mineralogical compositions, it was decided to take the SEM images of the loosened TLT coping concrete. Concrete samples were collected from the identified locations and Scanning Electron Microscope images were taken upon it from the reputed research lab.

\section{RESULT AND DISCUSSION}

The NDT results based on HCP, UPV and Rebound hammer are compared in the Table VI.

Table- VI: Non Destructive Test Values

\begin{tabular}{|c|c|c|c|c|c|c|c|}
\hline \multirow{2}{*}{$\begin{array}{c}\text { S } \\
\text { No }\end{array}$} & \multirow[t]{2}{*}{ Region } & \multicolumn{2}{|c|}{$\mathrm{HCP}(\mathrm{mV})$} & \multicolumn{2}{|c|}{ UPV (km/s) } & \multicolumn{2}{|c|}{$\begin{array}{l}\text { Average } \\
\text { Rebound } \\
\text { number }\end{array}$} \\
\hline & & $\begin{array}{l}\text { Least } \\
\text { Value }\end{array}$ & \begin{tabular}{|c} 
Highest \\
Value
\end{tabular} & $\begin{array}{l}\text { Least } \\
\text { Value }\end{array}$ & $\begin{array}{c}\text { Highest } \\
\text { Value }\end{array}$ & $\begin{array}{l}\text { Least } \\
\text { Value }\end{array}$ & $\begin{array}{c}\text { Highest } \\
\text { Value }\end{array}$ \\
\hline 1 & $\begin{array}{l}\text { Plain Region } \\
\text { (KPM-110 } \\
\text { kVSS) }\end{array}$ & -113 & -262 & 2.77 & 5.54 & 20 & 32 \\
\hline 2 & $\begin{array}{l}\text { Agricultural } \\
\text { (MTPS-230 } \\
\mathrm{kV})\end{array}$ & -215 & -349 & 3.0 & 3.9 & 17 & 38 \\
\hline 3 & $\begin{array}{l}\text { Coastal/Indu } \\
\text { strial } \\
\text { (NCTPS-23 } \\
0 \mathrm{kV})\end{array}$ & -330 & -640 & 1.73 & 3.29 & 10 & 29 \\
\hline
\end{tabular}

HCP test results taken from various TLTs are presented graphically in the Fig. Designation T1 to T10 represents the number of towers. Fig. 4 shows the test results of UPV in a graphical pattern. Rebound hammer test result are furnished in Fig. 5 and Mineralogical composition of soil and concrete samples are prescribed in the bar chart form in Fig 6 and 7.

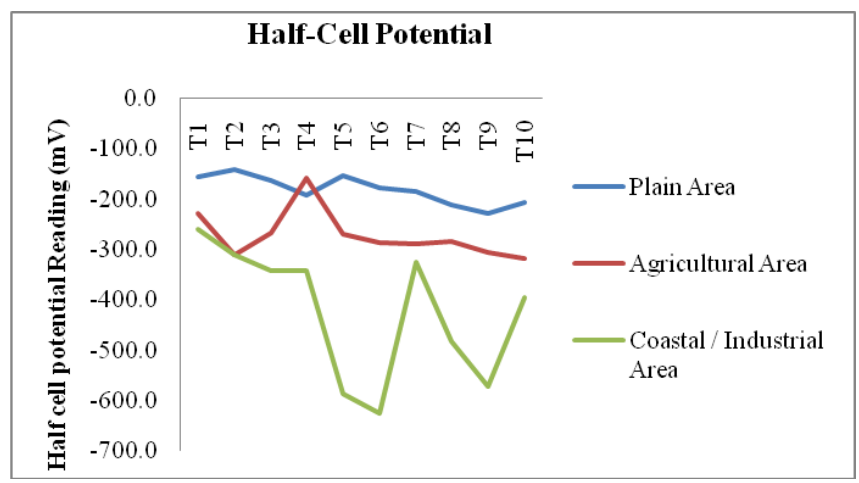

Fig. 3. Half Cell Potential reading

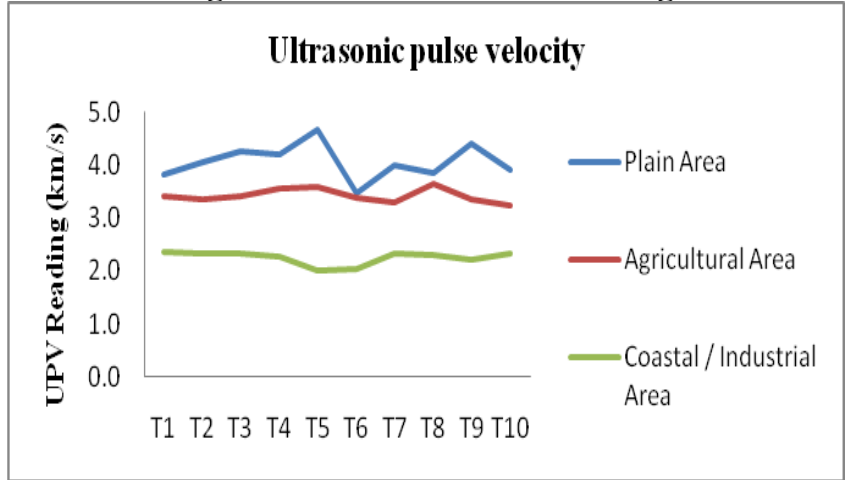

Fig. 4. Ultrasonic pulse velocity

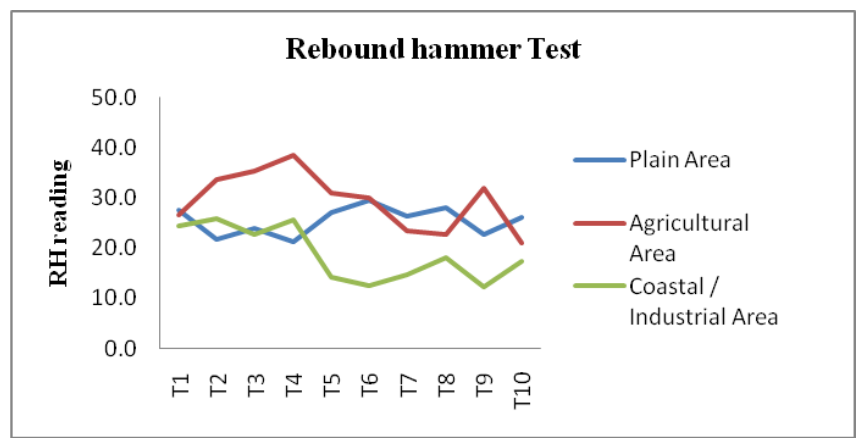

Fig. 5. Rebound hammer test reading

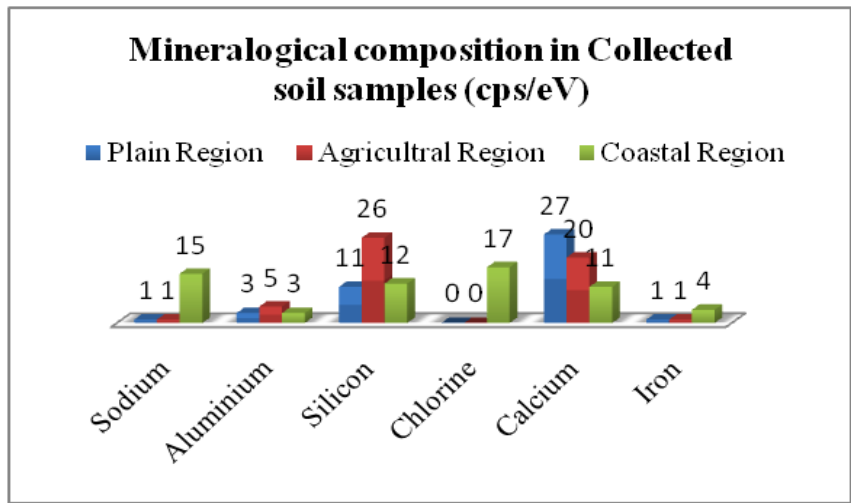

Fig. 6. Mineralogical composition of soil sample collected in different region

\section{Mineralogical composition of collected concrete samples}

(wt \%)

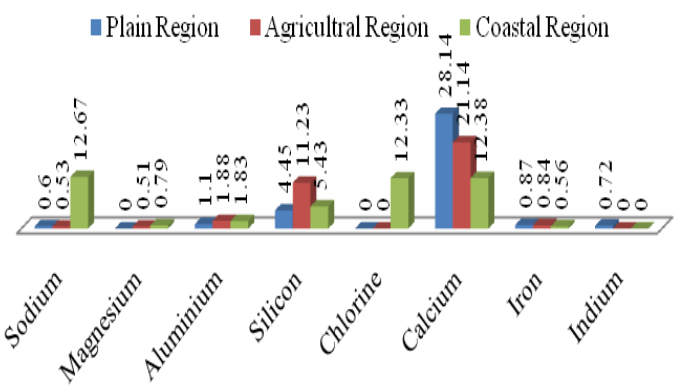

Fig. 7. Mineralogical composition of tower footing concrete sample

1) From the Fig. 6 and 7, It is observed that there is a correlation between calcium content present in the soil samples around the TLT in the different region and the corresponding TLT footing concrete samples.

2) Sodium, magnesium, aluminium, silicon, iron and indium are existing to a lower level both in soil samples and TLT footing concrete samples, but it is found that such chemicals are present in agricultural region 1-2\% higher than the plain region and 5-8\% higher in industrial region and chloride is predominantly present in the industrial region which is $8 \%$ higher than the agricultural region and $12 \%$ higher than the plain region.

3) The observation in the plain area is calcium content is more. This has kept the concrete in a good condition. All the test value are within the IS norms and hence mild corrosion.

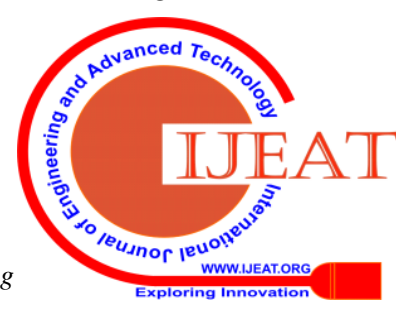


4) The extent of calcium in agricultural area is also reasonably higher than the industrial/coastal area hence only mild corrosion.

5) The extent of chloride content is more and the less calcium content in industrial area when compared to plain and agricultural area.
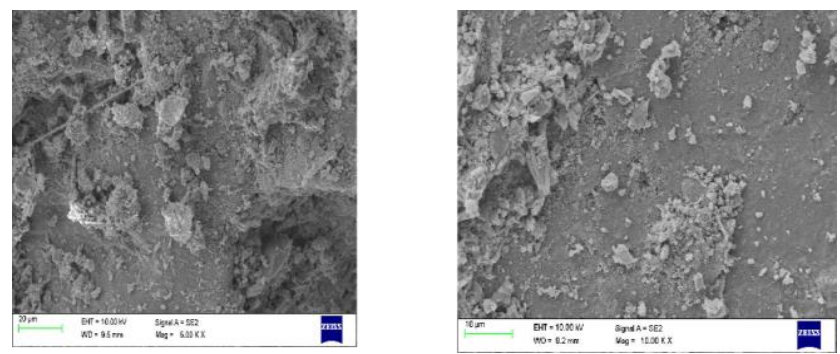

Fig. 8. SEM images of concrete sample in plain region
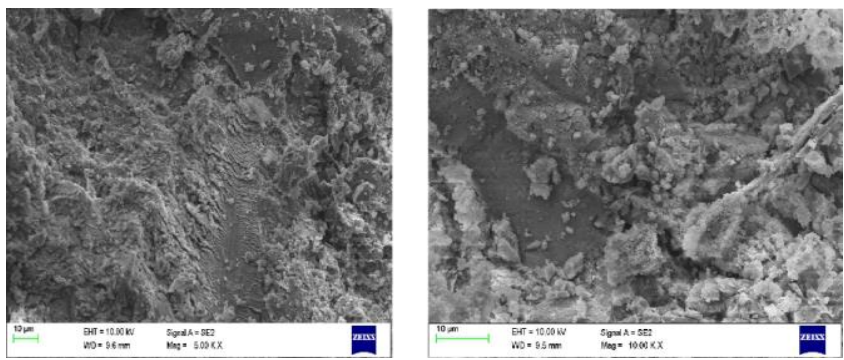

Fig. 9. SEM images of concrete sample in Agricultural region
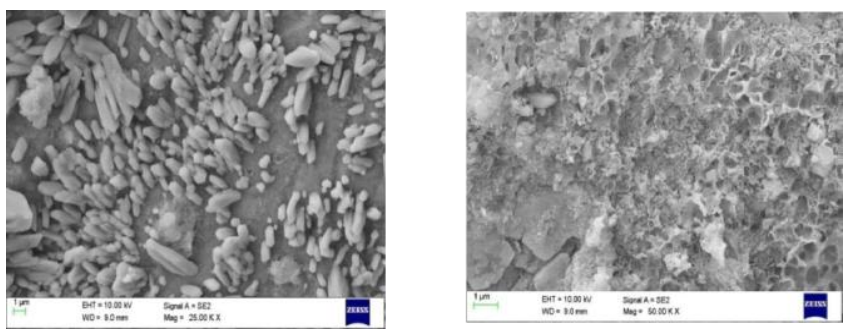

Fig. 10. SEM images of concrete sample in Coastal/Industrial region

6) As moderate environmental conditions are prevailing in the both the plain and agricultural area, the tower concrete is not much affected in this area and this can be recognized from the SEM images with less voids.

7) The identified area in the coastal area is surrounded by several industries and the intensity of environmental is very severe and hence lot of pores in the concrete to a larger extent.

8) This can be realized from the SEM images with big voids. The extent of corrosion/deterioration is reflected in the test values of non-destructive test results and chemical analysis of Soil/TLT concrete as well.

\section{CONCLUSION}

Transmission of Electric Power all over the world is mostly done through overhead lines. Incidences of corrosion in many cases across the world have led the Researchers to carry out research studies in the area of performance management of TLTs.

NDT methods tried in this work including chemical analysis of soil samples around TLT and TLT footing

concrete can be extended to other places also and be implemented by Power Transmission authorities.

\section{ACKNOWLEDGEMENT}

The Authors express their gratitude for the officials of TANTRANSCO for permitting us to conduct NDT's in the live towers and collect information from their office.

\section{REFERENCES}

1. S.Christian Johnson and Dr. G.Thirugnanam (2010) "Experimenta study on corrosion of transmission line tower foundation and its rehabilitation" International Journal of Civil and Structural Engineering, Volume: 01, Issue: 1, 2010, Pg no 27-34.

2. Peyman Taheri (2016) "Guide for cathodic protection of new and aging galvanized structures in transmission lines" CEATI INTERNATIONAL Inc, Canada, September 2016, Report no: TLAM T143700-3256

3. Mangesh V. Joshi (2015) "Novel technique of retrofitting of corrosion damaged RCC foundations of transmission towers exposed to marine environment", Master Builder Bureau, February 10, 2015

4. $\quad$ S.Christian Johnson et. al (2016) "Innovative methods for improving performance of transmission line tower foundations against corrosion in marine environment", Indian journal of geo marine sciences, vol. 47(1), Jan 2018, pp 200-208.

5. Matthew Bruce Barragan (2016) "Assessment, Prevention, and Remediation of corrosion in weathering steel transmission line poles" thesis of Master of science, University of south Carolina and CEATI International Inc, Canada.

6. Shyamala, G, (2016), “Application of integrated hydrochemical model and duster analysis in assessing groundwater quality", Journal of ecology and development, Vol.3, no. 4, pp. 34-45.

7. Shyamala, G, (2017), "Integrated weighted overlay model using inverse distance weightage for assessing Groundwater quality", Journal of Environmental Science and Management, Vol. 20, no.1, pp. 26-32

8. S.Christian Johnson et. al (2017) “ A new approaches for enhancing durability of transmission line tower foundations" CIGRE (C) 21, rue d'Artois, 75008 Paris - ISSN : 2426-1335, Pg no: 63-80.

9. ASTM 876 C-90, "Half-Cell potential methods for corrosion", American Society for Testing Materials, Philadelphia, U.S.A.

10. IS: 13311 (Part 1) (1992), "Methods of ultrasonic pulse velocity testing of concrete: Part 1', BIS, New Delhi, India

11. IS: 13311 (Part 2) (1992), "Methods of non-destructive testing of concrete: Part 2 Rebound hammer', BIS, New Delhi, India

12. IS: 5613 (Part 3/Sec-2):1989 "Code of practice for design, installation and maintenance of overhead power Lines”, BIS, New Delhi, India.

13. K. Rajesh Kumar, K.Karthik S Rammohan R, et al 4 (2019) "Shear resistance of portal frame Reinforced with Bamboo and Steel Rebar: Experimental and Numerical Evaluation", International Journal of recent Technology and Engineering issue 1, Vol. 8, pp.445-452.

14. A. Sivakrishna, A. Adesina , P.O. Awoyera , K. Rajesh Kumar, (2019) "Green concrete: A review of recent developments", Materials Today: Proceedings https://doi.org/10.1016/j.matpr.2019.08.202.

15. A. Adesina, P. O. Awoyera, A.Sivakrishna, K. Rajesh Kumar, (2019) "Phase change materials in concrete : an overview of properties", Materials Today: Proceedings DOI: 10.1016/j.matpr.2019.11.228.

16. P. O. Awoyera, A. Adesina, A.Sivakrishna, R.Gobinath, K.Rajesh Kumar, A.Srinivas, (2019) "Alkali activated binders: Challenges and opportunities", Materials Today: Proceedings https://doi.org/10.1016/j.matpr.2019.08.199

\section{AUTHORS PROFILE}

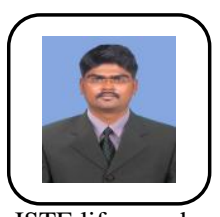

ISTE life member.
R.Krishnasamy, M.E in Structural Engineering, doing Ph.D in Anna University, presented and published paper in National/International conference which conducted by Central Board of Irrigation \& Power, Central power Research Institute and Cigre, doing research work in Overhead line tower structures.

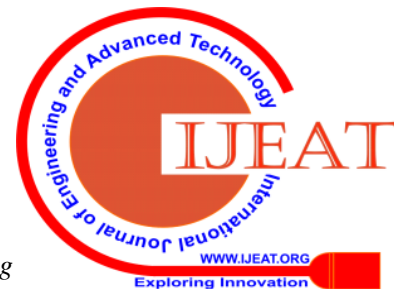


Dr.G.Shyamala, Ph.D has obtained her UG Degree in BE Civil from GCT, Coimbatore in the year 2003, M.E. Environmental Engineering from GCT, Coimbatore in the year 2005, and $\mathrm{PhD}$ in Civil Engineering from Anna University in the year 2017. She began his career as a Lecturer in Sasurie College of Engineering in the year 2005 and presently she is working as Professor at S R
mingeering College, Warangal. She has published 22 papers in conferences and 19 articles in Journals

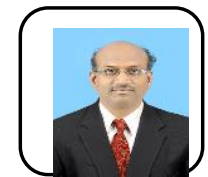

Dr.S.Christian Johnson has obtained his UG Degree in BE Civil from Annamalai University in the year 1988, PG in M.Tech (Aero Structures) from I.I.T Mumbai in the year 1990, MBA (HRD) from Annamalai University in the year 2006 and $\mathrm{PhD}$ in Civil Engineering from Anna University in the year 2012. He began his career as a Lecturer in Bharath Vidyapeeth's College of Engineering at New Mumbai in the year 1990 and subsequently at National Aeronautical Laboratory (NAL), Bangalore as Post Graduate Trainee during 1991-92. From Feb 1992 to June 2012, he worked in various capacities in Tamil Nadu Electricity Board for 20 years. As Dean/IQAC he served at Excel Engineering College, Komparapalayam for about 6 years from 2012 to 2018. From July 2018 to till date he has been working as Director/Academics at Erode Sengunthar Engineering College, Perundurai. He is member of professional bodies like ICI, ISTE, CIGRE and fellow of IE (I) and IOV beside a Charted Engineer. As the member of CIGRE, he is the secretary of one of the working group B2.65 CIGRE and presently involved in compiling a CIGRE technical brochure on Detection, Prevention, Repair of sub surface corrosion in over head power Line Foundations. He has published 26 papers in conferences and 22 articles in Journals and authored 6 text books. Guided about 15 PG (ME) Projects and 20 UG (BE) projects. Presently 4 Research Scholars are pursuing their PhD Under his guidance beside PG and UG students. E-Mail: cjnlef@gmail.com (M) 9865426597.

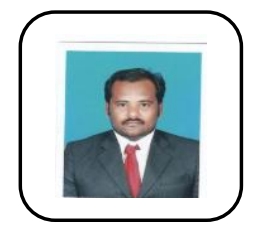

K.Sabarinathan, M.E in Structural Engineering, doing Ph.D in Anna University, working Assistant Professor, Civil Department, Excel Engineering College, Namakkal. Doing research work in Recycle concrete aggregate. ISTE life member.

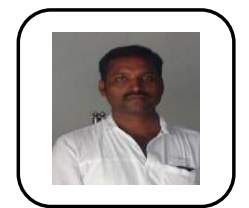

S.M.Sakthivel, M.E in Structural Engineering, working Assistant Professor, Civil Department, Excel Engineering College, Namakkal.

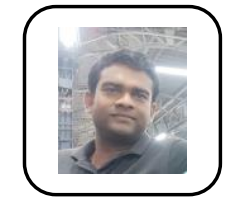

Dr.K.Rajesh Kumar, Ph.D is working as Associate Professor at S R Engineering College, Warangal. He has published 20 papers in conferences and 17 Technical Paper in Journals 